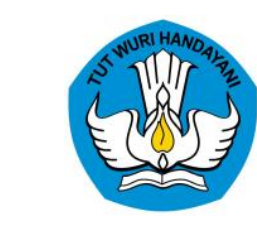

Check for updates

\title{
VARIETIES AND ORIGINS OF KAMPAI ISLAND GLASS BEADS ${ }^{1}$
}

\author{
Ery Soedewo \\ Balai Arkeologi Sumatera Utara \\ J1. Seroja Raya, Gg. Arkeologi, Medan 20134, Indonesia \\ soedewo_ery@yahoo.com \\ Received: 03/10/2018; revisions: 21/10 - 20/12/2018; accepted: 20/12/2018 \\ Published online: 31/12/2018
}

\begin{abstract}
The glass beads discovered in various archaeological sites in South Asia and Southeast Asia between the $1^{\text {st }}$ and $13^{\text {th }}$ centuries were generally referred to as Indo-Pacific glass beads. Various shapes and colors of glass beads are found on Kampai Island, Langkat Regency, Sumatera Utara. Collected data of glass beads were obtained from archaeological excavations in Kampai Island. In analyzing varieties of glass beads, this study characterizes the variety of Kampai Island glass beads based on their typology and frequency, i.e., drawn glass beads and wound glass beads. A number of these glass beads were analyzed in the laboratory to identify the composition of the ingredients. In determining the origin of glass beads production, this study used a comparative method on some published research. Through comparison of the findings of glass beads wastes from Arikamedu and glass beads production centers in Papanaidupet (India) and Gudo (Indonesia), the result finds that Kampai Island was a glass beads production site in the Malacca Strait region between $11^{\text {th }}-14^{\text {th }}$ centuries. The emergence of Kampai island as a glass beads production site in the 11th century was likely a result of geopolitical conditions. Glass bead making traditions spread to Kampai Island as Cōla Kingdom influences rose in Malacca Strait region after its expansion to several places in that region.
\end{abstract}

Keywords: glass beads; Kampai Island; Malacca Strait; production; waste

\section{INTRODUCTION}

The history of glass beads in Southeast Asia may be traced back to the industry in Arikamedu, India referred to as the "mother site" of the artifact class by Francis (1991c). Before the total abandonment of Arikamedu, many glass beadmakers migrated to Sri Lanka (Mantai) and the Southeast Asian Mainland (Klong Thom in Thailand and Oc-Eo in Vietnam) around the $2^{\text {nd }}$ century. (Francis, 1991c: 101-102). After the destruction of Mantai by the Cōla kingdom during the $10^{\text {th }}$ century, a large number of beadmakers had returned to South India. However, the destruction of Mantai (Ceylon) came later after that of the Southeast Asian glass bead centers at the end of the $6^{\text {th }}$ or early of the $7^{\text {th }}$ century. While the end of glass bead centers at Oc-eo (Vietnam) was due to the Khmer invasion, the end of Klong Thom (Thailand) has not yet been determined (Francis, 1991c: 103).

After the abandonment of Oc-eo (Vietnam) and Klong Thom (Thailand), other glass beadmaking centers were created in Kuala Selinsing (Malaysia) and Sating Pra (Thailand), which were soon deserted at the $10^{\text {th }}$ century, coinciding with the collapse of Mantai (Sri Lanka). The end of Kuala Selinsing and Sating Pra was followed by the rise of other glass beadmaking centers of Sungai Mas (Kedah, Malaysia) and Takua Pa/Kakao Island (Thailand), which was one of the last production sites to be identified in Southeast Asia. At the early of the $14^{\text {th }}$ century, both Sungai Mas and Takua Pa were no longer productive (Francis, 1991c: 104).

The glass beads discovered in various archaeological sites in South Asia and Southeast Asia (mainland and archipelago) between the $1^{\text {st }}$ and $13^{\text {th }}$ centuries were generally referred to as Indo-Pacific glass beads, with the dominant type was the red glass beads that were known as mutisalah in Indonesia (Lamb, 1965a: 93). Mutisalah is the Bahasa Indonesian/Bahasa Malay word for "false pearl." Mutisalah beads do not resemble true mollusk pearls, but the term suggests an analogy to several other languages-including Latin, Greek, French, and German

\footnotetext{
${ }^{1}$ This article was a part of an ongoing dissertation by the author as a doctoral candidate in Archaeology at the Doctoral Study Programs of Humanities, the Faculty of Cultural Sciences, Universitas Gadjah Mada.
} 
in which the word for "pearl" is cognate with "bead." The root of the word, moti, is Sanskrit for "pearl," but is often used in modern Hindi to mean "glass bead" as well (Francis, 1991b). Mutisalah distribution stretched as vast as Southern India, the Southeast Asian mainland, and Island Asian (The Philippines and Indonesia) (Lamb, 1965a: 94). Arikamedu was one of the mutisalah production sites found in India, while in mainland Southeast Asia, there was Pengkalan Bujang (Malaysia) (Lamb, 1965a: 95).

The results of the study of the ingredients of the glass beads of Kampung Sungai Mas site by Ramli and Rahman (2009: 151) showed that Indo-Pacific glass bead from this site used Sodium as the alkali material, while those of Arikamedu used Potassium. This information suggests that Southeast Asian glass beads makers had their signature compounds in making beads, different from South Asia. However, the original places of the glass used for the Indo-Pacific was made is still an unanswered matter. The Indo-Pacific glass beads from various location such as Arikamedu, Karaikadu, Oc-Eo, Kuala Selinsing, Sungai Mas, Khlong Thom, and Takua $\mathrm{Pa}$ has been undergone through several scientific research. The result shows that there are differences in terms of element composition for each bead in their respective areas (Ramli et al., 2017). The Sungai Mas site was the center of Indo-Pacific glass beadmaking between the $8^{\text {th }}$ and $11^{\text {th }}$ centuries. The rise of Sungai Mas was due to the migration of Indo-Pacific glass beadmakers from South India (Ramli \& Rahman, 2009: 154). Such a proposition was then strengthened by further analysis by Ramli, Rahman, and Jusoh (2012) then confirmed the previous assumption (Ramli \& Rahman, 2009) that the glass beads of Sungai Mas and Oc-Eo (Vietnam) were of different ingredients, which opposed similar data from Arikamedu. Thus, it may be concluded that the Indo-Pacific drawn beads discovered in Southeast Asian sites, especially Oc-Eo (Vietnam) and Sungai Mas (Malaysia) were locally produced rather than imported from Arikamedu (India) (Ramli, Rahman, \& Jusoh, 2012: 28).

The following studies on glass beads and other Southeast Asian glass artifacts were done by Dussubieux \& Allen (2014). They utilized data of glass container fragments and glass beads from Malay Peninsula sites such as Pengkalan Bujang and Sungai Mas, as well as the comparative data from Sumatran sites such as Lobu Tua, Bukit Hsang, Sipamutung, Kuta Kareueng, and Kota Cina. Other analyzed comparative data was taken from such sites as Ko Kho Khao and Laem Pho (Thailand), as well as glass artifacts of Chinese junk remains from Brunei (Dussubieux \& Allen, 2014: 129). The analysis result suggested that along the $9^{\text {th }}$ and $11^{\text {th }}$ centuries there were three main ingredients of glass artifacts in Southeast Asia, it consist of v-Na-Ca 1, v-Na-Ca 2, and $\mathrm{v}-\mathrm{Na}-\mathrm{Ca} 3$, which originated from Near East or Middle East glass artifact making tradition (Dussubieux \& Allen, 2014: 130). The $11^{\text {th }}$ century witnessed the rise of a new

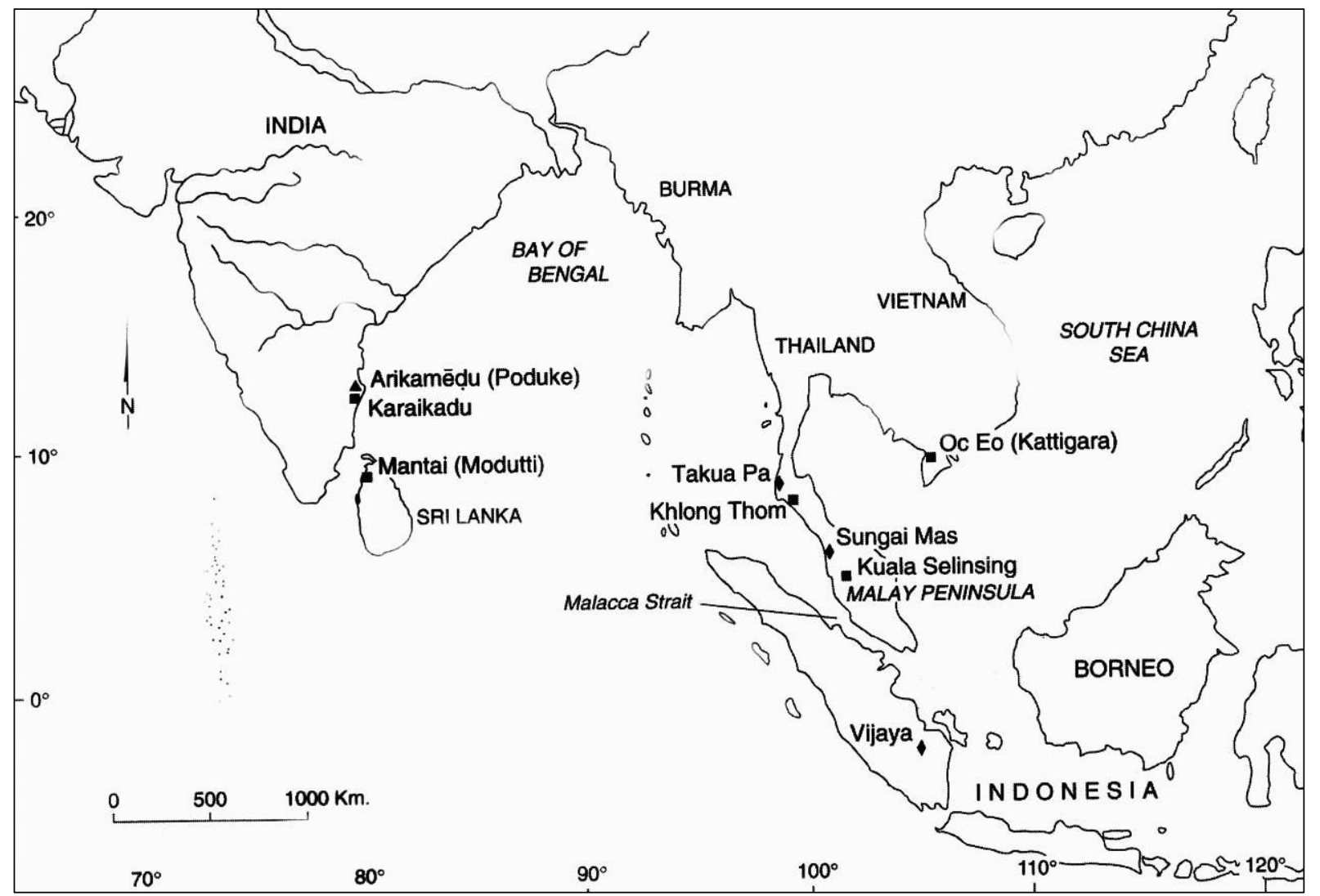

Figure 1. The location of Indo-Pacific beads production

(Source: Francis, 2002) 
type of glass artifact composed from v-Na-Al that lasted until the $13^{\text {th }}$ century. The $14^{\text {th }}, 15^{\text {th }}$, and $16^{\text {th }}$ centuries saw the development of different glass artifact compositions in South Asia (Dussubieux \& Allen, 2014: 130). On the other hand, while it has been widely known that Indo-Pacific types dominated Indian and Mainland Southeast Asian glass beads, glass beads found in Singapore were influenced by the Chinese beadmaking tradition, which is identifiable through the high lead composition. A study on some glass bead samples from Singapore, Palembang, and Kepulauan Tujuh (Riau) suggested that the Singapore and Palembang glass beads originated from different glass bead trade networks, while the Singapore and Kepulauan Tujuh (Riau) were of the same origin (Miksic et al., 1994: 46).

The glass beads discovered in the west side of the Malacca Strait were revealed through some research at archaeological sites in North and South Sumatera. The North Sumatran sites containing glass beads are Kampai Island, Kota Cina, Lobu Tua and Bukit Hasang (Barus), and Sipamutung (Padang Lawas). Between 1974-1978, 2,421 pieces of glass beads were discovered, which were dominated by Indo-Pacific monochrome glass beads of dark red/brown (mutisalah), black, yellow, green, and blue colors; (McKinnon \& Sinar, 1981: 59). The ingredients of the glass beads of 2013's Kampai Island research results have been analyzed using Inductively Coupled Plasma-Mass Spectrometer (ICP-MS). The analysis result suggested that Kampai Island glass beads are mostly influenced by Indian glass bead tradition, while the less dominant beads were of Middle Eastern tradition (Soedewo, 2013; Dussubieux \& Soedewo, 2016: 1-11). Dark red/brown (mutisalah), black, yellow, blue, green, and buff monochrome glass beads dominated the glass bead finding at the Kota Cina site. Two lumps of a dark blue glass of 10 and $15 \mathrm{~cm}$ diametres combining with 2 or 3 glass beads found at Kota Cina site provide some hints on glass beads making (McKinnon, 1984: 115). On the other hand, Lobu Tua site glass bead finds were dominated by yellow, blue, and brown Indo-Pacific type and a small number of polychrome glass beads. Furthermore, despite the absence of raw glass materials, Lobu Tua seemed to have been a glass bead making center, which is indicated by the finding of some glass bead lumps (Guillot et al., 2008: 266-268). The glass bead finding at Bukit Hasang was marked by the dominant monochrome drawn and wound glass beads, and only two pieces of polychrome glass beads (Perret, 2015: 365-367). The Sipamutung excavation in Padang Lawas revealed the dominant monochrome bluish-green, dark blue, black, turquoise, red, yellow, green, and blue glass beads, and four least dominant two-tone glass beads (Perret, 2014: 343-344). Another site in North Sumatra containing glass beads is Candi Simangambat, located in Mandailing Natal Regency, where along with gold pieces and cornelian

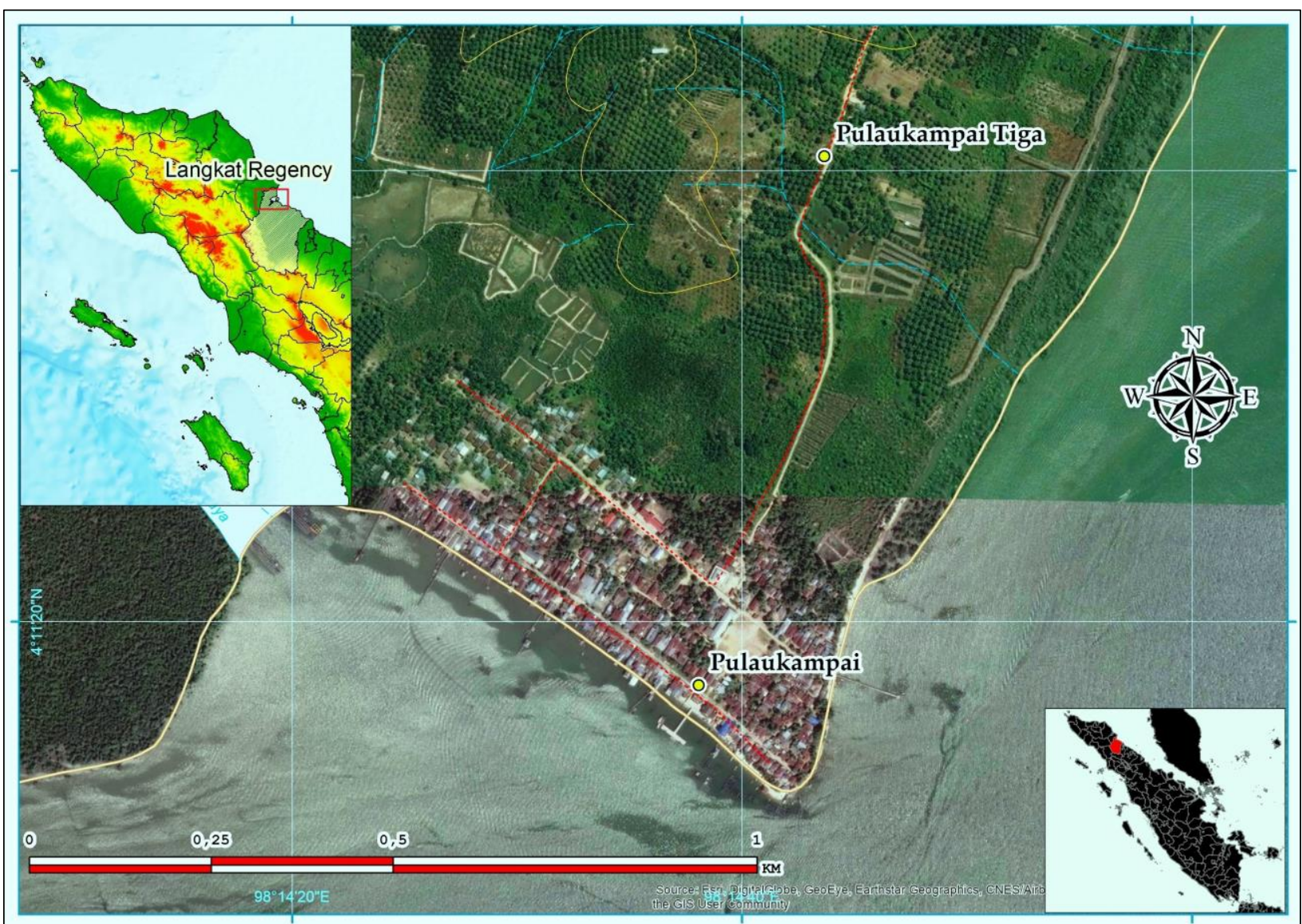

Figure 2. Crowded settlements at the south part of Kampai Island (Source: ESRI World Imagery 2018, edited by Author) 


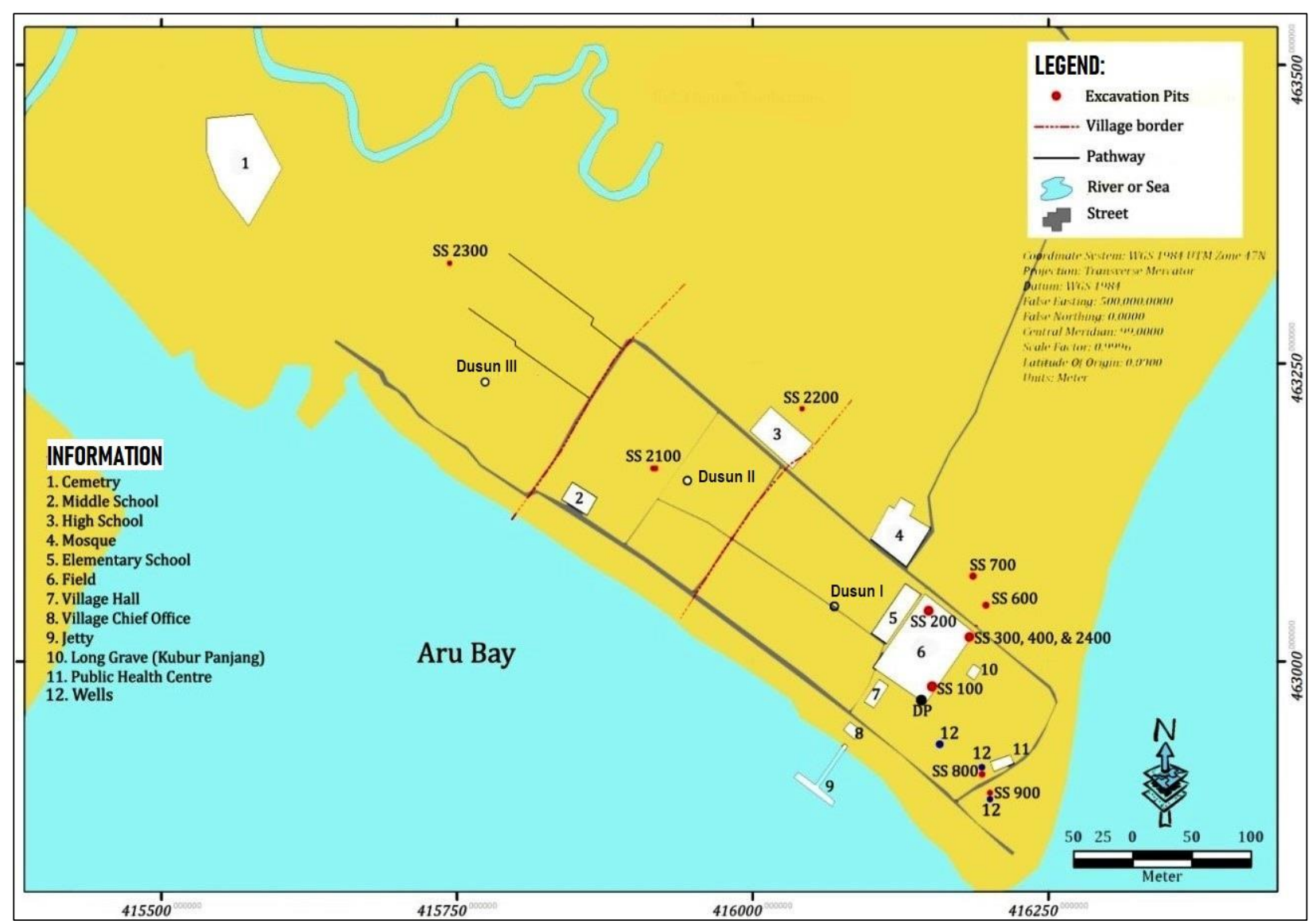

Figure 3. The location of excavation pits at Kampai Island site

(Source: Research data by Author)

stone beads, white and green opaque glass beads were found in sacred deposits (peripih/garbhapātra) of terracotta pots (Soedewo, 2014a: 98-99; Soedewo, 2014b: 190).

Glass beads were also discovered in the South Sumatra at Candi Astano (at the Muaro Jambi temple complex) which are 700 glass beads along with the hints of making were found (Perret, 2015: 366; Soekatno, 1985). At Karangberahi site in Jambi, blue and brownish red (mutisalah) glass beads were found in sacred deposits (peripih/garbhapātra) terracotta pots (Purwanti, 1996: 30-32). To the south of both sites was Kemiling site near Pugung Raharjo, where 3,000 glass beads with Chinese making tradition signatures were found (Ferdinandus, 1998: 94; Perret, 2015: 366). Various studies on Southeast Asian glass beads, both in the mainland or archipelago, describe the dominance of the monochrome glass beads known as the Indo-Pacific glass beads. Experts agree that since the beginning of the century of the Common Era, Indo-Pacific glass beads originated from India and spread to Ceylon and Southeast Asia, where indications of the hints of the spread of the Indo-Pacific glass beadmaking were identified. Despite being known as a rich site of glass beads, Kampai Island needs more in-depth studies on its variety and frequency. This article characterizes the variety of Kampai Island glass beads based on their typology and frequency as well as the possible existence of production centers based on the materials found in some excavation pits of the island.

\section{MethodS}

This study is part of the results of archaeological research that took place on Kampai Island around 2011 to 2016. Collected data of glass beads were gathered from the findings of each archeological site through conscientious excavation all around of Kampai Island. For the analysis, in order to analyze varieties of glass beads, this study characterizes the variety of Kampai Island glass beads based on their typology and frequency, i.e., drawn glass beads and wound glass beads. A number of these glass beads are analyzed in the laboratory using Inductively Coupled Plasma-Mass Spectrometer (ICPMS) connected to the laser New Wave UP213 to identify the composition of the ingredients. In determining the origin of glass beads production, this study used a comparative method on some published research.

\section{RESUlt AND DiscuSSION}

The Variety and Abundance of Glass Beads in Kampai Island

Kampai Island an island in Aru Bay, Pangkalan Susu, Langkat Regency, Sumatera Utara Province. The archaeology of the island was first revealed by McKinnon and Sinar (1981: 57-73) based on their survey 
of the island from 1974 until 1977. After the 1970s observations, Kampai Island was under another survey in 2010 by a joint team of the Centre of Social Studies of Universitas Negeri Medan and Balai Arkeologi Medan. Museum Negeri of Sumatera Utara Province then furthered this initial step by conducting surveys and excavations in 2011. Based on the 2010's observations and surveys and 2011's excavations, Balai Arkeologi Medan conducted more systematic research on Kampai Island in 2013, 2014, and 2016. Excavations in twelve pits, which were all in the south part of the island, uncovered the remnants of ancient cultures of various artifacts, ecofact, and features. The artifacts found were ceramics, potteries, metals, stones, and glass objects, one of which was glass beads. The frequency of the artifacts indicated prosperity of Kampai Island which lasted between the $11^{\text {th }}$ and $14^{\text {th }}$ centuries but declined drastically at the end of the $14^{\text {th }}$ century.

Kampai Island glass beads were excavated in 2013, 2014, and 2016 from twelve pits in the southern parts of the island. The excavation pits were mostly located in the east of the southern part of the island, which administratively belonged to Dusun I, Dusun II, and Dusun III, Kampai Island village. The pieces of land used as the excavation pits were located in crowded areas; thus, they were literally among local people's houses (see Figure 2), except for the pits in the front yard of Kampai Island state elementary school, as seen on the following map (see Figure 3). Most glass beads were found in excavation pit 2400, surpassing the overall finding of all glass beads in each excavation pit. The twelve pit excavations resulted in the finding of 5,786 pieces of glass beads with the following details showed by Table 1 .

\section{The Typology of Kampai Island Glass Beads}

Based on the making technique, Kampai Island glass beads can be divided into two groups, i.e., drawn glass beads and wound glass beads. The drawn glass beads are generally cylindrical, such as the yellow drawn glass beads from (a) excavation pit 300 and (b) orange drawn glass beads from excavation pit 700. Different from the typically cylindrical drawn glass beads, the wound glass beads are more varied in shapes, such as the dark red double conical beads from (c) excavation pit 300 and (d) the yellow ones from excavation pit 700. Another shape of the wound glass beads is disc such as (e) dark red disc beads from excavation pit 300 and (f) the green ones from the excavation pit 300. Another type of wound glass beads is polychrome such as $(\mathrm{g})$ a combination of purple and white from excavation pit 300 and (h) a combination of black and white from excavation pit 400 (see Figure 5). The total number of the collected glass beads from three excavation seasons in 2013, 2014, and 2016 are 5,786 pieces either intact or broken, 4,279 of them were cylindrical of various color such as brown/dark red (mutisalah), yellow, green, blue, and black. The making technique is dominated by the drawn one with more than $73 \%$ of the overall identified glass beads. The remaining 1,507 beads are $(26 \%)$ wound glass beads of disc and double-cone shapes and various colors of monochrome: dark red, yellow, black, green,

Table 1. Details frequency of glass beads finding in excavation pits at Kampai Island

\begin{tabular}{lccccccccccccc}
\hline $\begin{array}{l}\text { Excavation } \\
\text { Pits }\end{array}$ & $\mathbf{1 0 0}$ & $\mathbf{2 0 0}$ & $\mathbf{3 0 0}$ & $\mathbf{4 0 0}$ & $\mathbf{6 0 0}$ & $\mathbf{7 0 0}$ & $\mathbf{8 0 0}$ & $\mathbf{9 0 0}$ & $\mathbf{2 1 0 0}$ & $\mathbf{2 2 0 0}$ & $\mathbf{2 3 0 0}$ & $\mathbf{2 4 0 0}$ & Total \\
\hline Frequency & 720 & 370 & 656 & $\mathbf{2 8 8}$ & $\mathbf{2 8 9}$ & 132 & 308 & 280 & 46 & 357 & 4 & 2,336 & $\mathbf{5 , 7 8 6}$ \\
\hline Weight (g) & 52.1 & 52.3 & 99.2 & 58.3 & 9.8 & 11 & 17.1 & 18.9 & 12.8 & 34.3 & 2 & 188.2 & $\mathbf{5 5 6}$ \\
\hline
\end{tabular}

Source: Research data by Author

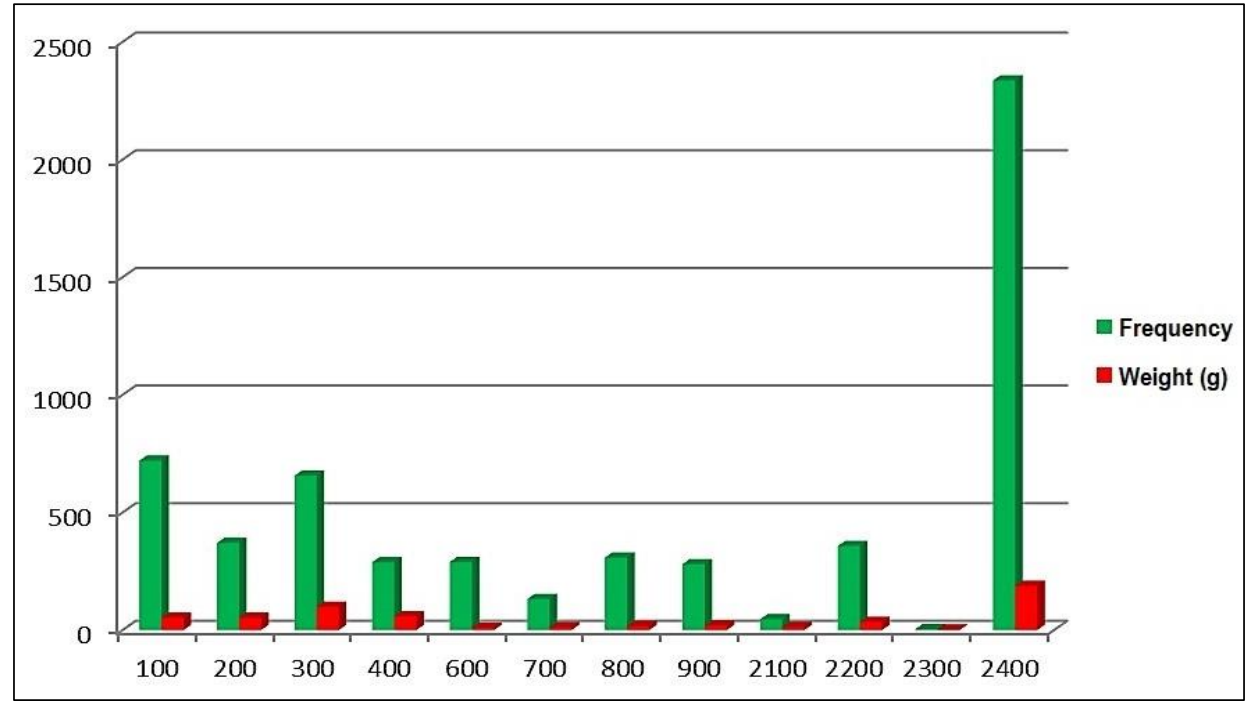

Figure 4. Chart details of glass beads frequency in excavation pits at Kampai Island (Source: Research data by Author) 


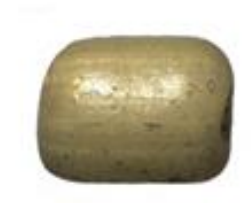

a

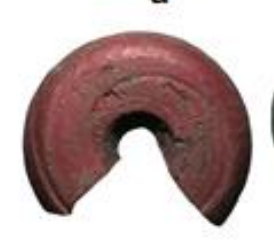

e

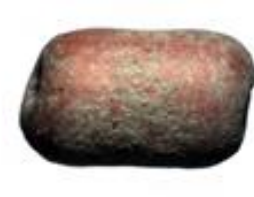

b

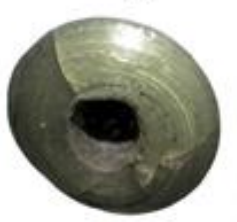

f

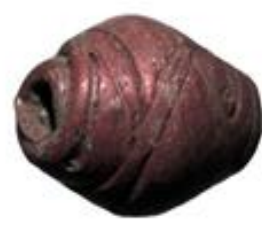

C

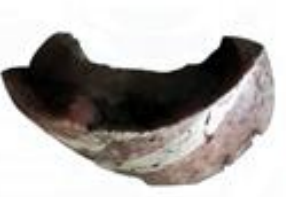

g

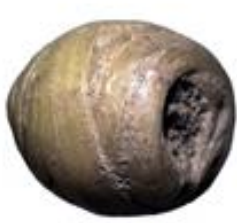

d

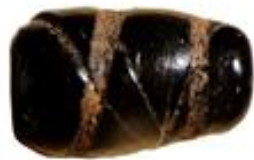

h

Figure 5. Varieties of shapes and colours of Kampai Island glass beads (Source: Research data by Author)

Table 2. The frequency of the glass beads variety

\begin{tabular}{|c|c|c|c|c|c|c|c|c|c|c|c|c|c|}
\hline \multicolumn{13}{|c|}{ Drawn Glass Beads } & \multirow[t]{2}{*}{ Total } \\
\hline Excavation Pit & 100 & 200 & 300 & 400 & 600 & 700 & 800 & 900 & 2100 & 2200 & 2300 & 2400 & \\
\hline Frequency & 674 & 356 & 448 & 267 & 260 & 110 & 304 & 254 & 40 & 295 & 4 & 1,267 & 4,279 \\
\hline \multicolumn{13}{|c|}{ Wound Glass Beads } & \multirow{2}{*}{ Total } \\
\hline Excavation Pit & 100 & 200 & 300 & 400 & 600 & 700 & 800 & 900 & 2100 & 2200 & 2300 & 2400 & \\
\hline Frequency & 46 & 14 & 208 & 21 & 29 & 22 & 4 & 26 & 6 & 62 & 0 & 1,069 & 1,507 \\
\hline \multicolumn{13}{|c|}{ Grand Total } & 5,786 \\
\hline
\end{tabular}

Source: Research data by Author

and polychrome of black and white, orange and white, and green and yellow. 68 out of 5,786 glass beads have been analyzed at the Field Museum of Natural History in Chicago, United States of America using Inductively Coupled Plasma-Mass Spectrometer (ICP-MS) connected to the laser New Wave UP213 to enable direct introductions against such solid samples as the glass beads (Dussubieux, 2014; Dussubieux, 2015; Dussubieux \& Soedewo, 2016: 3). The sample analysis exposed two main groups of glass beads based on the major and minor ingredients. Both groups are composed of soda as the second mostly-used ingredient after silica, but they differ on oxide concentration. The following are the glass beads discussed (Dussubieux \& Soedewo, 2016: 5):

- The first group is glass beads of high degree of alumina (m-Na-Al) with lower than $1.5 \%$ magnesium concentration suggesting that the glass was produced using a high degree of soda mineral and alumina sand.

- The second group is glass beads of lower degree of alumina (m-Na-Al) with more than $1.5 \%$ kalium and magnesium concentration suggesting that the glass was produced using lower degree plant ash soda and alumina sand.

Based on ICP-MS analysis showed that glass beads with high degree alumina belong to monochrome types a-f drawn and wound glass beads, while those with the lower alumina belong to polychrome glass beads of types $\mathrm{g}$ and $\mathrm{h}$. This suggests that most Kampai Island glass beads (up to 5,769 pieces or $99.70 \%$ ) owed their provenance to northeastern India and western India, which are dominated by dark red (mutisalah), yellow, and black cylindrical drawn and wound glass beads known as Indo-Pacific glass beads. The remaining 17

Table 3. The content of alumina in glass beads ingredients

\begin{tabular}{|c|c|c|c|c|c|c|c|c|c|}
\hline \multicolumn{9}{|c|}{ Glass beads with high alumina of all excavation pits } & \multirow{2}{*}{ Total } \\
\hline Type & a & b & c & d & e & $f$ & g & $\mathbf{h}$ & \\
\hline Frequency & 2,538 & 1,566 & 173 & 265 & 579 & 648 & 0 & 0 & 5,769 \\
\hline \multicolumn{9}{|c|}{ Glass beads with low alumina of all excavation pits } & \multirow{2}{*}{ Total } \\
\hline Type & a & b & c & d & e & $f$ & g & $\mathbf{h}$ & \\
\hline Frequency & 0 & 0 & 0 & 0 & 0 & 0 & 2 & 15 & 17 \\
\hline \multicolumn{9}{|c|}{ GRAND TOTAL } & 5,786 \\
\hline
\end{tabular}


middle eastern $(0.29 \%)$ beads are those of low degree alumina.

Dussubieux and Soedewo's study (2016: 11) on glass beads from the similar site Kampung Sungai Mas, Malaysia ( $9^{\text {th }}$ until $11^{\text {th }}$ centuries) revealed that this site contained Indian and Middle Eastern glass beads. Despite their shared similar Indian and Middle East origin, the ingredient trace patterns of the glass beads of Kampai Island and Kampung Sungai Mas showed that the beads originated from more specifically different production centers with Kampung Sungai Mas beads which is came from southern India and Iran/Iraq. Glass beads of Kampai Island were imported from western and northeastern India and Near East, especially Egypt. Dussubieux and Soedewo (2016: 11) proposed that this study result indicated various trade patterns that seemed to begin after the $11^{\text {th }}$ century.

\section{Indications of Production}

Kampai Island holds both identifiable glass beads and peculiar objects whose shape and material resemble glass beads. To explain these peculiar Kampai Island objects, a comparative study using Francis's study (1991a), which analyzed similar objects found in Arikamedu site, was carried out. Such objects as glass and stone beads like those of Kampai Island were also located in this east coast Indian Arikamedu site. The data studied by Francis (1991a: 28-43) the beads from Arikamedu and other sites stored in Pondicherry museum. One of the objectives of the research on Arikamedu beads by Francis (1991a) was to identify this site function as a glass bead production center.

To answer his research question, Francis (1991a: 30) observed the peculiar glass objects, contextual to glass beads, he suspected as glass bead production wastes. To prove his assumption, Francis (1991a: 29-32) carried out an ethnographic study on traditional beadmaking centers in Papanaidupet village, Chittoor district, Andhra Pradesh state. In his research, Francis observed the tools, production stages, end results, and production wastes. His observations confirmed his assumption that the peculiar glass objects found in Arikamedu and its surrounding sites were indeed the wastes of glass bead production. The varied shapes of Papanaidupet's glass bead wastes were the production wastes of glass bead making stages.

There are six types of wastes Papanaidupet glass beadmaking identified by Francis (1991a: 32), i.e.:

a) a knot, formed when refractory matter is caught in tube;

b) and (c) are amorphous and curved tubes from a failed initial draw;

c) a flake of glass from gedda paru ${ }^{2}$ tool;

d) a clump of beads stuck together when being reheated and tumbled;

e) a collapsed tube from the very end of the draw.

Based on the comparison between the wastes of Papanaidupet glass beadmaking and the peculiar glass bead objects contextual to Arikamedu glass beads, Francis (1991a: 40) concluded that the presence of the peculiar objects of Arikamedu was a proof of Arikamedu's past existence as a glass bead production center. To confirm that the peculiar glass objects of Kampai Island are indeed glass bead wastes, a comparative study with similar data analysis by Francis (1991a: 28-43) was once again done. The Kampai Island's compared data was mostly taken from the excavation pit 300 , located in the front yard of public elementary school 050 778, Kampai Island, with only one piece was taken from the excavation pit 800 .

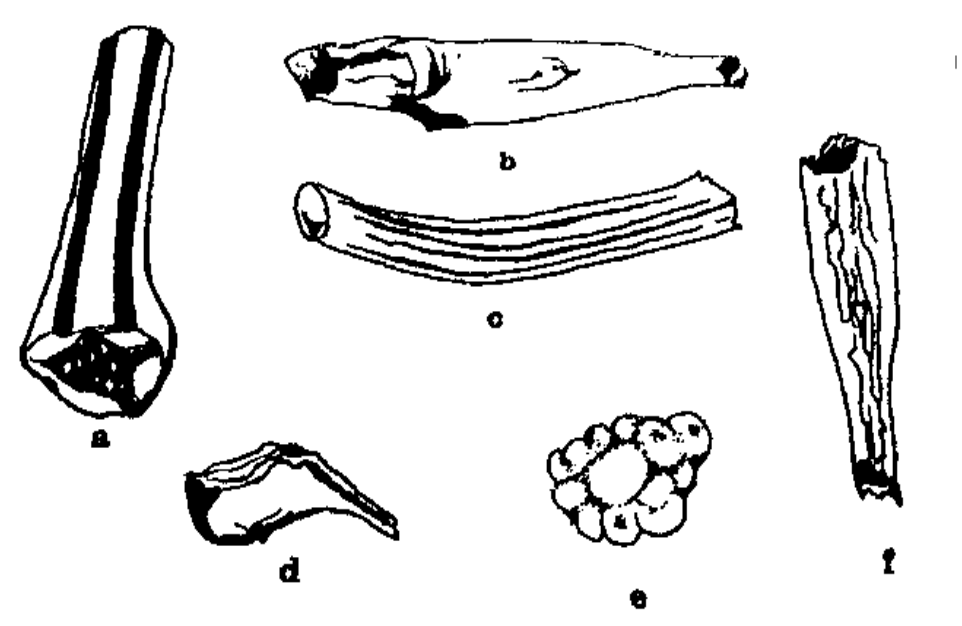

Figure 6. Glass bead wastes from Arikamedu site, India (Source: Francis, 1991a: 32)

${ }^{2}$ Metal pipe used to stir the glass in the furnace 


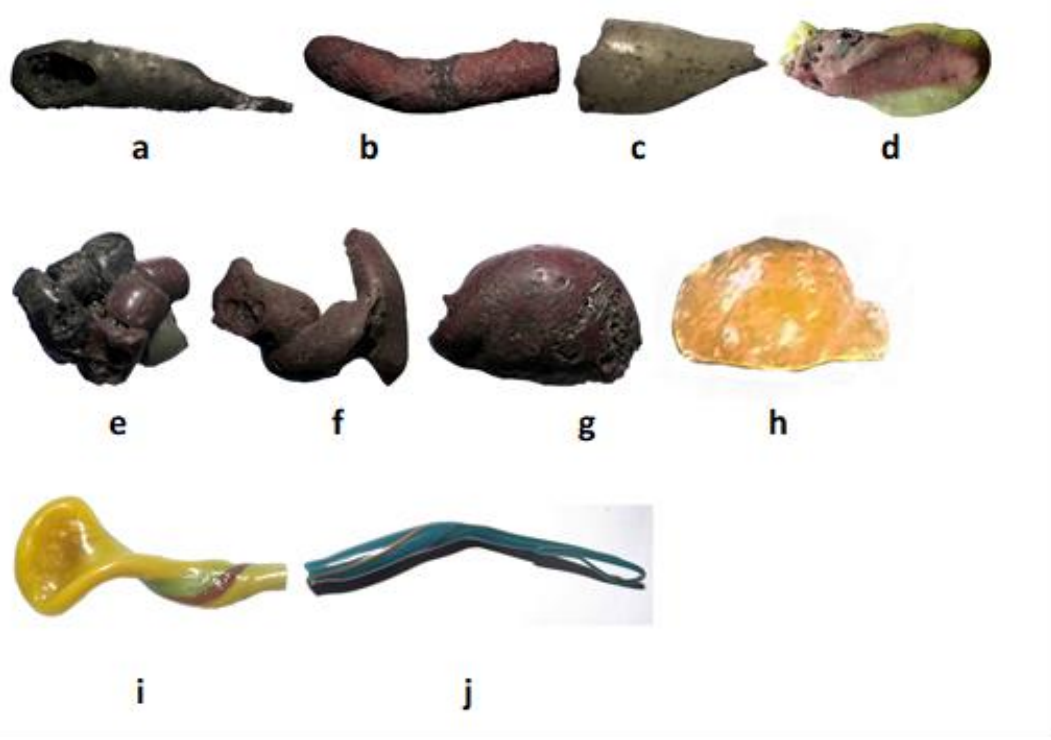

Figure 7. (a-g) The wastes of Kampai Island's glass beads and (h-j) of a glass beadmaking centre in Gudo village, Peterongan district, Jombang regency, Jawa Timur

(Source: Research data by Author)

The morphology of Kampai Island's glass bead wastes resemble those of Arikamedu and the tradition of Papanaidupet's glass beadmaking are, among others, the wastes from the excavation pit 800 (type a in Figure 7) and the excavation pit 300 (type b in Figure 7) that are amorphous and curved tubes from a failed initial draw (see type $\mathrm{b}$ and $\mathrm{c}$ wastes from Arikamedu and Papanaidupet sites in Figure 6). The next glass bead wastes are from the excavation pit 300 (type $\mathrm{c}$ in Figure 7) that are shaped collapsed tube from the very end of the draw (see type $\mathrm{f}$ wastes of Arikamedu and Papanaidupet in the Figure 6). The next glass bead wastes are those of the excavation pit 300 (type e in the Figure 7) that are shaped a clump of beads stuck together when being reheated and tumbled (see the type e wastes of Arikamedu and Papanaidupet in the Figure 6). The next glass bead wastes are those of the excavation pit 300 (type $g$ in the Figure 7) that are a flake of glass from gedda paru tool (see type d wastes of Arikamedu and Papanaidupet in the Figure 6).

Beside the inter-site comparison, observations on glass bead wastes were also done on the glass bead production wastes of a glass bead workshop in Gudo village, Peterongan district, Jombang regency, East Java province. Glass beadmaking in Gudo employed a combined technique of drawn and wound glass beadmaking as opposed to the drawn technique used in
Papanaidupet. The following are the varieties of glass bead wastes identified through the ethnographic study in Gudo village:

a) The type $h$ glass bead wastes in the Figure 7 . These wastes have a similar shape of type $d$ wastes of Arikamedu and Papanaidupet in the Figure 6 and the type $\mathrm{g}$ wastes of Kampai Island in the Figure 7 that is a flake of glass from gedda paru tool.

b) The type i polychrome glass bead wastes in the Figure 7. Observations in a glass bead production workshop in Gudo village revealed that the wastes were the flakes of the end of a glass rod obtained during the making process of polychrome drawn glass beads. Their shapes resemble Kampai Island's type d glass wastes in the Figure 7. This kind of wastes was absent from both Arikamedu and Papanaidupet glass beadmaking workshops.

c) Type $\mathrm{j}$ polychrome glass bead wastes in the Figure 7. Observations in a glass bead production workshop in Gudo village revealed that the wastes were the flakes of the tip of a glass bar obtained during the making process of polychrome drawn glass beads. Their shapes resemble Kampai Island's type c glass wastes in the Figure 7, and types $\mathrm{b}$ and $\mathrm{c}$ wastes of Arikamedu and Papanaidupet in Figure 6 that are collapsed tube from the very end of the draw.

Table 4. The frequency of glass bead wastes

\begin{tabular}{cccccccccccccc}
\hline \multicolumn{10}{c}{ Excavation Pits } & Total \\
\hline 100 & 200 & $\mathbf{3 0 0}$ & $\mathbf{4 0 0}$ & $\mathbf{6 0 0}$ & $\mathbf{7 0 0}$ & $\mathbf{8 0 0}$ & $\mathbf{9 0 0}$ & $\mathbf{2 1 0 0}$ & $\mathbf{2 2 0 0}$ & $\mathbf{2 3 0 0}$ & $\mathbf{2 4 0 0}$ & \\
\hline 0 & 0 & 38 & 17 & 3 & 8 & 6 & 3 & 1 & 3 & 0 & 485 & 564 \\
\hline
\end{tabular}

Source: Research data by Author 


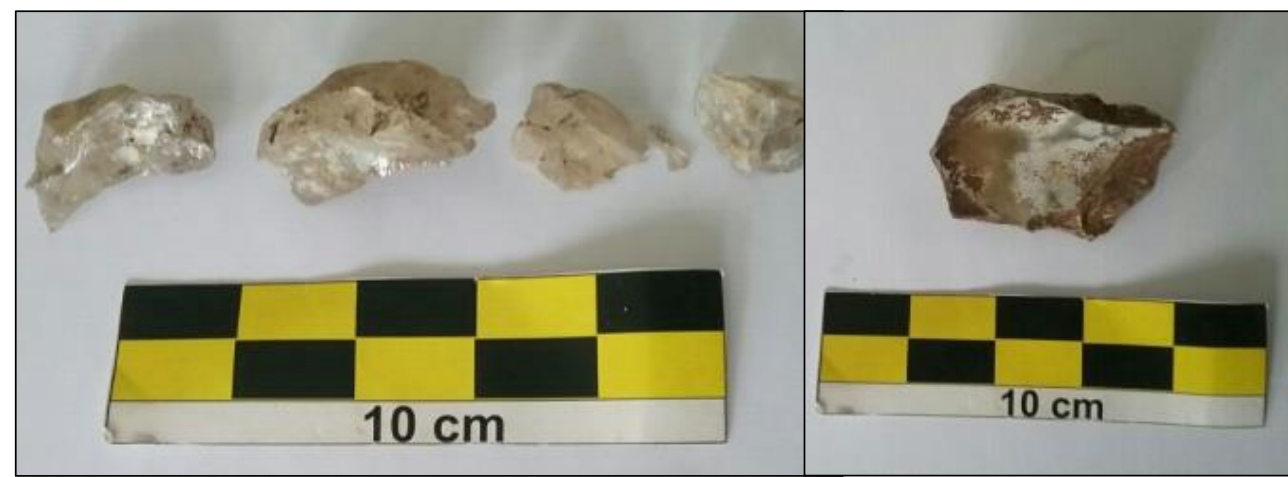

Figure 8. Glass lumps SS 2102 (left) \& SS 2206 (right)

(Source: Research data by Author)

The comparisons of the peculiar glass objects found in Kampai Island and similar objects from such sites as Arikamedu (India) and the wastes of glass beadmaking from Papanaidupet (India) and Gudo village, Jombang (East Java province) confirmed that the peculiar glass objects of Kampai Island are indeed glass beadmaking wastes. Analyses on the frequency of glass bead wastes of all excavation pits came with 564 pieces of wastes, the 485 pieces of which were found in the excavation pit 2400 ; it means that $89 \%$ of the glass bead wastes were found in the excavation pit located in the northeast side of the front yard of Kampai Island's public elementary school. This data suggests that the production center of glass beads in Kampai Island was located in the vicinity of the excavation pit 2400 covering excavation the excavation pits 300 and 400 .
Aside from possession of the glass bead wastes of identified similarity with the compared data from Arikamedu and Papanaidupet (India) as well as ethnographic data from glass beadmakers of Gudo village, Kampai Island also holds another shape of wastes not found in both Indian sites and Gudo workshop. This shape of wastes may further confirm Kampai Island possible past existence as a glass bead production center. This unique shape is lumps of glass found in the excavation pits 2100 and 2200. The excavation pit 2100 owns 4 colorless transparent glass lumps, while the excavation pit 2200 has transparent greenish lumps. Glass lumps indicating a site as a production center have been found in various mainland Southeast Asian sites such as Klong Thom (Thailand), Sating Pra (Thailand), Takua Pa (Thailand), Kuala Selinsing (Malaysia), and
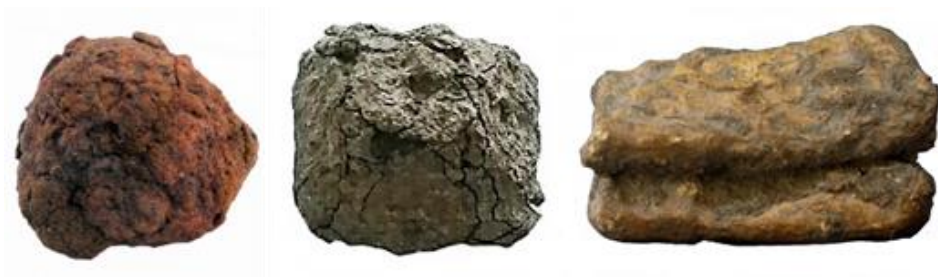

Figure 9. Iron ingot, tin-truncated pyramid-ingot, lead bar (left to right) (Source: Research data by Author)

Table 5. A comparison of the density of glass beads in North Sumatran glass bead sites

\begin{tabular}{lccccc}
\hline Sites & KC 1975-1977 & KC 2011-2013 & BKH 2001-2004 & PMTG 2006-2009 & PK 2013-2016 \\
\hline Dimension of excavation $\left(\mathbf{m}^{2}\right)$ & 120 & 185 & 470 & 1,092 & 50 \\
\hline Volume of excavation $\left(\mathbf{m}^{3}\right)$ & 120 & 120 & 390 & 553 & 35 \\
\hline Frequency $(\mathrm{n})$ & 200 & 124 & 1,222 & 4,175 & 5,786 \\
\hline Weight $(\mathrm{g})$ & - & - & - & - & 556 \\
\hline Frequency $\left(\mathbf{n} / \mathrm{m}^{\mathbf{2}}\right)$ & 1.6 & 0.67 & 2.6 & 3.82 & 115.72 \\
\hline Frequency $\left(\mathbf{n} / \mathrm{m}^{3}\right)$ & 1.6 & 1.03 & 3.13 & - & 165.31 \\
\hline Weight $\left(\mathrm{g} / \mathrm{m}^{2}\right)$ & - & - & - & - & 11.12 \\
\hline Weight $\left(\mathrm{g} / \mathrm{m}^{3}\right)$ & - & - & - & 15.88 \\
\hline
\end{tabular}

Source: KC, BKH, PMTG: Perret et.al., 2013: 105 
Sungai Mas (Malaysia). According to Lamb (1965b: 36), the glass lumps were brought to Southeast Asia from the Middle East as cargo in trade boats. Those objects were then utilized as raw materials for glass beadmaking in Southeast Asia.

Other supporting data of Kampai Island's past existence as a production center were some pieces of metal of iron ingot $(\mathrm{Fe})$ from the excavation pit 500, tin (Sn) ingot from the excavation pit 2200, and lead $(\mathrm{Pb})$ ingot from the excavation pit 900. These metal findings are most likely related with glass beadmaking in Kampai Island in the past, serving as a mixing element making up a certain color in the produced glass beads. Accordingly, Dussubieux and Soedewo (2016: 9) stated that Kampai Island' amber and black glass beads contain high degree of iron of $1.7-6.7 \%$, the opaque and green glass beads contain high degree of tin and lead of $1-7 \%$ (Dussubieux \& Soedewo, 2016: 10), and turquoise blue glass beads contain $a$ high degree of tin and lead (Dussubieux \& Soedewo, 2016: 9).

A number of indications such as the shared shapes of glass beads and the presence of glass lumps found in the excavation pits 2100 and 2200 may explain why Kampai Island owns more glass beads than other North Sumatran sites such as Kota Cina (KC), Bukit Hasang (BKH), and Sipamutung (PMTG) that share approximately similar periodization, between the $11^{\text {th }}-14^{\text {th }}$ centuries (see Table 5 ). The analyses of frequency and weight of the glass beads of the North Sumatran sites suggest that Kampai Island was the site with most glass bead findings. Such a fact plus the findings of wastes and building materials of glass bead confirm the Kampai Island's status as a production hub of Indo-Pacific drawn and wound glass beads of various shapes and colors between the $11^{\text {th }}$ and $14^{\text {th }}$ centuries.

Dussubieux and Soedewo (2016: 1-16) stated that the analyses of the ingredients of Kampai Island glass beads revealed their origins of east and northeast India and the Middle East. Such fact may be interpreted as an indication that the glass beadmaking of Kampai Island was based on the Indian traditions. The dark red/brown (mutisalah), yellow, and black cylinder drawn glass beads of Indian glass beadmaking traditions found in Kampai Island were found intact and in wastes. On the other hand, the glass beads that shared similar ingredients with the Middle Eastern glass beads suggest direct or indirect trade interactions involving the production sites and the traders with the parties in Kampai Island.

The rise of Kampai Island as a glass bead production hub in the $11^{\text {th }}$ century was most likely related with the then geopolitical condition in South and Southeast Asia. The invasion of Cōla Kingdom to some places in India and Southeast Asia's mainland and archipelago at the beginning of the $11^{\text {th }}$ century altered the then geopolitical order in the Indian Ocean to the Malay Strait. During Rajendra Cōladeva's reign, Cōla Kingdom's colonies covered the southern Indian Ocean of Ceylon, Maldives, and the northern Indian Ocean of Benggala. Rajendra Cōladeva continued his expansion as far as the Malacca Strait covering Srivijaya, Kadaram (Kedah), Pannai (Pane or Panai), Malayur (Malayu), and Ilamuridesam (Lamuri) (Kulke, 2009: 3).

Despite the small political significance, the invasions gained Tamil a special place in the trade routes of the Indian Ocean, Malacca Strait, and the South China Sea. The direct impact of Cōla Kingdom's invasions was the presence of Tamil's merchant-guild in various places across the Indian Ocean, Malacca Strait, and the South China Sea. It might be very likely that Cōla's dominance over the ports of southern Indian west coast (Malabar), southern Indian east coast (Coromandel), and Bay of Bengal (northeast India) had pushed glass bead makers to join onboard Tamil's merchant-guild sail to Cōla's newly-conquered territories to expand their new production hubs. This event may explain the presence of glass beads of similar ingredients from west India (Malabar) and northeast India (Bengal) in Kampai Island since the $11^{\text {th }}$ century.

\section{CONCLUSION}

Most glass beads found in Kampai Island are colorful (dominantly dark red/brown (mutisalah), yellow, and black) and cylindrical drawn and wound glass beads. Based on their abundant findings, the presence of variedly-shaped glass bead waste resulting from various stages of making, and glass lumps from excavation pits, it may now be safely stated that between the $11^{\text {th }}$ and $14^{\text {th }}$ centuries, Kampai Island was a glass bead production hub. The rise of glass bead production in Kampai Island was closely related with the geopolitical condition at the beginning of the $11^{\text {th }}$ century of Cōla's invasions to various places in South Asia and Southeast Asian (mainland and archipelago). The invasions drove away from the production places in the invaded areas to such a new place as Kampai Island.

This initial opinion needs confirming in the future intensive research to attest its validity. Future research needs to confirm the presence of a furnace for glass bead making which may be based on the frequency and wastes of the glass bead that has been found. The predicted location is somewhere in the northeast of the front yard of Kampai Island's public elementary school, or more precisely around the excavation pits 300, 400, and 2400, from which new excavation pits need to be opened to ascertain the whereabouts of the furnace. To further our understanding of Kampai Island's glass bead assemblage, the wasters need to be analyzed to compare and contrast with the precious analysis at the Field Museum of Natural History in Chicago, the United States of America. 


\section{ACKNOWLEDGEMENT}

This article is part of an ongoing dissertation by the author as a doctoral candidate in Archaeology, in the Doctoral Study Programs of Humanities, the Faculty of Cultural Sciences (Fakultas Ilmu-ilmu Budaya), Universitas Gadjah Mada. The author would like to acknowledge the BU (Beasiswa Unggulan) scholarship fund, awarded by the Republic of Indonesia's Ministry of Education and Culture (Kementerian Pendidikan dan Kebudayaan), for its financial support. My gratitude goes to Prof. Dr. Bambang Purwanto, M.A. and Dr. Widya Nayati, M.A. which has provided input in the writing of this article. My grartitude also to Dr. Daniel Perret for giving inputs to the initial draft of this article. Thank you to all team members on Kampai Island research 2013, 2014, and 2016: Andri Restiyadi, M.A.; Ariananta, S.T.; Dedi Satria, S.S.; Dr. Dwi Wahyuni Nurwihastuti, S.Si., M.Sc.; Dra. Jufrida; Drs. Lucas P. Koestoro, D.E.A.; Pesta H. H. Siahaan; R. Wahyu Oetomo, S.S.; Stanov Purnawibowo, M.A.; and Taufiqurrahman Setiawan, M.A., for their contributions during research.

\section{$* * * * *$}

\section{REFERENCES}

Dussubieux, L. (2014). Compositional analysis of ancient glass fragments from Si Pamutung, North Sumatra. Cahier d'Archipel, 42, 383-404.

Dussubieux, L. (2015). Analisis Komposisi Bahan Kaca Kuno dari Bagian Utara Sumatra. In D. Perret \& H. Surachman (Eds.), Barus Negeri Kamper Sejarah Abad ke-12 hingga Pertengahan Abad ke-17 (pp. 385-418). Jakarta: Kepustakaan Populer Gramedia, École Française d'Extrême-Orient, Pusat Arkeologi Nasional.

Dussubieux, L., \& Allen, J. (2014). Compositions of glass artifacts from Malaysia: new data from the sites of Pengkalan Bujang and Sungai Mas. In Perret \& D. Z. B. Jaafar (Eds.), Ancient Glassware in Malaysia: The Pengkalan Bujang Collection (pp. 119-161). Kuala Lumpur: Department of Museums Malaysia.

Dussubieux, L., \& Soedewo, E. (2016). The glass beads of Kampai Island, Sumatra. Archaeological and Anthropological Sciences, 10(4), 1-16.

Ferdinandus, S. U. (1998). Archaeological Sites in Pugung Raharjo, Province of Lampung, Sumatra. In P. Y. Manguin (Ed.), Southeast Asian Archaeology 1994: Proceedings of the 5th International Conference of the European Association of Southeast Asian Archaeologists Paris, 24th-28th October 1994 (pp. 91-96). Hull: Centre for Southeast Asian Studies.

Francis, J. P. (1991a). Beadmaking at Arikamedu and Beyond. World Archaeology, 23(1), 28-43.
Francis, J. P. (1991b). Beads in Indonesia. Asian Perspectives, $30(2), 217-241$.

Francis, J. P. (1991c). Glass Beads in Malaya: a reassessment. Journal of the Malaysian Branch of the Royal Asiatic Society, 64(1), 97-118.

Francis, J. P. (2002). Asia Maritime, Bead Trade 300 B.C to the Present. Honolulu: the University of Hawai'I Press.

Guillot, C., Perret, D., \& Fanani, A. S. (2008). Barus Seribu Tahun yang Lalu (No. 9). Jakarta: Kepustakaan Populer Gramedia, École Française d'Extrême-Orient, Association Archipel, Pusat Penelitian Arkeologi Nasional, Forum Jakarta-Paris.

Kulke, H. (2009). The Naval Expeditions of the Cholas in the Context of Asian History. In Nagapattinam to Suvarnadwipa: Reflections on the Chola Naval Expeditions to Southeast Asia (pp. 1-19). ISEAS-Yusof Ishak Institute.

Lamb, A. (1965a). Some Observations on Stone and Glass Beads in Early South-East Asia. Journal of the Malaysian Branch of the Royal Asiatic Society, 38(2 (208), 87-124.

Lamb, A. (1965b). Some glass heads from the Malay Peninsula. Man, 65, 36-38.

McKinnon, E. E., \& Sinar, T. L. (1981). A Note on Pulau Kompei in Aru Bay, Northeastern Sumatra. Indonesia, (32), 49-73.

McKinnon, E. E. (1984). Kota Cina: Its Context and Meaning in the Trade of Southeast Asia in the Twelfth to Fourteenth Centuries;(volumes I and II). Doctoral dissertation, Cornell University.

Miksic, J. N., Yap, C. T., \& Younan, H. (1994). Archaeology and early Chinese glass trade in Southeast Asia. Journal of Southeast Asian Studies, 25(1), 31-46.

Perret, D. (2014). Glassware from Sipamutung. In D. Perret, \& H. Surachman (Eds.), History of Padang Lawas II: Societies of Padang Lawas (mid-9 $9^{\text {th }}-13^{\text {th }}$ century CE) (pp. 335-378). Paris: Cahier d'Archipel 43.

Perret, D. (2015). Kaca. In D. Perret, \& H. Surachman (Eds.), Barus Negeri Kamper Sejarah Abad ke-12 hingga Pertengahan Abad ke-17 (pp. 331-384). Jakarta: Kepustakaan Populer Gramedia, École Française d'Extrême-Orient, Pusat Arkeologi Nasional.

Perret, D., Surachman, H., Soedewo, E., \& Oetomo, R. W. (2013). The French-Indonesian Archaeological Project in Kota Cina (North Sumatra): Preliminary Results and Prospects. Archipel, 86, 73-111.

Purwanti, R. (1996). Struktur Bangunan Situs Karangberahi: Sebuah Mandala? Kalpataru, 11.

Ramli, Z., \& Rahman, N. H. S. N. A. (2009). Penyelidikan dan Penemuan Manik di Lembah Bujang. In N. H. S. N. A. Rahman, W. S. W. Ibrahim, \& N. I. A. A. Rahman (Eds.), Prosiding Seminar Pembangunan Warisan Kerajaan Melayu Lembah Bujang (p. 137-156). Kedah Darul Aman: Universiti Kebangsaan Malaysia, Universiti Teknologi Mara.

Ramli, Z., Rahman, N. H. S. N. A., \& Jusoh, A. (2012). Sungai Mas and OC-EO Glass Beads: A Comparative Study. Journal of Social Sciences, 8(1), 22-28.

Ramli, Z., Rahman, N. Q. A., Hussin, A., Nur, S., Hasan, I. S., \& Dali, A. M. (2017). Compositional Analysis of Sungai Mas, Kuala Selinsing and Santubong Glass Beads. Mediterranean Archaeology and Archaeometry, 17(2), 117-129.

Soedewo, E. (2013). Perkembangan Penelitian Kepurbakalaan di Pulau Kampai, Sumatera Utara. Archipel, 86, 131-154.

Soedewo, E. (2014a). Latar Belakang Penempatan dan Fungsi Peripih (Garbhapatra) Candi Simangambat. In Sumatra Utara: Catatan Sejarah dan Arkelogi (pp. 89-118). Yogyakarta: Penerbit Ombak. 
Soedewo, E. (2014b). Archaeological Remains Displaying Indian Cultural Influence in the Region of the Batang Gadis and Batang Angkola Rivers, Mandailing Natal Regency, North Sumatra. In D. Perret, \& H. Surachman (Eds.), History of Padang Lawas II: Societies of Padang Lawas (mid-9th-13th century CE) (pp. 183-210). Paris: Cahier d'Archipel 43.

Soekatno, E. S. (1985). Beads from Muara Jambi. In SPAFA Consultative Workshop on Archaeological and Environmental Studies on Srivijaya (pp. 307-310). Jakarta, Padang, Prapat, and Medan: Southeast Asian Ministers of Education Organization. 